\title{
Mendu, Whose has it? (The Miserable Fate ofthe Traditional Theater Mendu West Kalimantan)
}

\author{
Gunta Wirawan $^{1}$, Herman J. Waluyo ${ }^{2}$, Sarwiji Suwandi ${ }^{3}$, Sahid Teguh Widodo ${ }^{4}$ \\ 1,2,3. Faculty of Teacher Training and Education, Universitas Sebelas Maret, Surakarta \\ Indonesia; \\ 4. Faculty of Cultural Sciences, Universitas Sebelas Maret, Surakarta, Indonesia. \\ ${ }^{1}$ gwirawan91@gmail.com, ${ }^{2}$ hermanjwaluyo@staff.uns.co.id, \\ ${ }^{3}$ sarwijiswan@staff.uns.co.id, ${ }^{4}$ sahidteguhwidodo@yahoo.com
}

\begin{abstract}
Who owns the traditional theater of mendu? This satire question is very intriguing considering that mendu is a typical art of West Kalimantan which originates from Malikian, Mempawah District. The people of West Kalimantan are the legal owners of the art. However, the rapid modernization has a negative impact on the sustainability of the mendu. Mendu slowly began to be abandoned by the community supporters. The question that arises then is whether mendu's traditional theater is seen as a memory or a legacy? If its only considered a memory, it is enough to be an archive stored in the museum. However, if there is still concern to regard it as an inheritance, it means that all parties must be responsible for preserving it. This study attempts to describe the factors causing the decline of the West Kalimantan mendu. The method used is descriptive qualitative form. Data collection techniques are done by studying the text (literature study), interviews, and observations. The study is done by classifying the parts that are the object of research. The results of the study revealed the factors that caused the loss of the glory of mendu which should have become a cultural treasure of West Kalimantan.
\end{abstract}

Keywords: traditional theater, mendu, heritage, preservation.

\section{INTRODUCTION}

Indonesia which is very rich in cultural and traditional customs, certainly cannot be separated from the adverse effects of globalization[1][2][3][4][5]. As a result, traditions began to be abandoned, culture began to fade due to the onslaught of new types of popular culture, and folk arts were considered to have given no satisfaction to the world of entertainment, rigid, impractical and out of date. The younger generation prefers to enjoy art through mobile phones, the internet, cinema and television. Entertainment options also vary, ranging from modern films, various genres of music, online games, or sitting in a cafe to spend the night. Entertainment is not monotonous as in the era of the 80 s which merely presents stories of kingdoms or heavenly countries that don't make sense.

The rapidity of various means of communication and information turned out to have a significant influence on the existence of traditional performing arts. Traditional arts groups 
began to disappear, due to the lack of a supporting factor in the form of funds, capacity or regeneration. Therefore, they cannot compete with the emergence of modern art forms which are more in demand by the people of today[6]. Young generations start to behave individualistically as they are used to modern facilities and thus no longer need to be in direct contact with their peers. They are also accustomed to something instant as the impact of globalization and modernization that persistently offer ease and speed in accomplishing things $[1]$.

Watching a show in a luxurious and cool building is certainly more comfortable than jostling in a field, just fulfilling mere entertainment desires. Moreover, it turned out that the stage witnessed was far from perfect, ranging from improvised decoration, a buzzing and inaudible sound system, to costumes and performers that were not clearly visualized, the audience was no longer bewitched by hilarious scenes, and royal stories that seemed boring. The main thing is watching traditional art is not like watching action movies in a cinema with a booming sound system, more attractive women, handsome men, and fascinating and thrilling action. All of this is certainly difficult to obtain in traditional performing arts.

In the past, traditional performing arts had an important role in the culture of the community, apart from being a medium of entertainment it also became an archive of noble values of local wisdom, education, social control, and religious facilities [7][8][9]. Parents told me, how they were waiting for the performance of the performing arts, both traditional theater, storytelling, dancing and so on. There is indeed some kind of magical effect that is eager to immediately come to the stage when the gong, drum or drum beaten. However, this is only the stories of previous people, now everything seems to have ended.

One of the arts that is quite alarming is the traditional theater of mendu, West Kalimantan. Based on preliminary observations to a number of high school students and college students showing that in general the young generation did not know the traditional theater of mendu, some of them already knew this theater but were less interested in watching the show because they thought this entertainment was no longer in line with the current era, they were behaving do not care because assume is not part of the culture of young people. Traditional theater is only for the consumption of old folk who are old-fashioned and have become memories of the past. Of course this assumption is a serious problem for the continuation of mendu's traditional theater, as well as other traditional arts[10].Many young people do not care about the special arts of the region which should be a cultural heritage and treasure of West Kalimantan Malay.

Who is the owner of mendu? This question is a hard slap for the community of supporters as a form of scathing satire to be able to shoulder responsibility. All returned to the people of West Kalimantan, whether to let it extinct or feel called to preserve and develop it. The key question is whether mendu's traditional theater is seen as a memory or a legacy? If it is only considered a memory, it is enough to be an archive stored in the museum. However, if there is still concern to consider it as an inheritance, it means that all parties must be responsible for preserving it because inheritance is an infinite amount of wealth if it is utilized and utilized as much as possible.

This research does not discuss which area the real owner of mendu. Is it West Kalimantan or Riau Islands? Of course, to determine who is actually the owner of a traditional theater mendu requires in-depth and accurate research, given that this old art has both lived in West Kalimantan and Riau Islands communities for hundreds of years ago. Therefore, the government of the Republic of Indonesia through the Ministry of Education and Culture took the middle road by establishing the mendu as an intangible cultural heritage shared by West Kalimantan and the Riau Islands since 2014[11]. 
This stipulation means that there is government interference in the maintenance of cultural treasures so that they do not become extinct from Malay soil. The government has made policies and various strategies. EvenUNESCO has conducted a study of tradition in Malaysia and Indonesia[12]. However, this was felt to be insufficient without the role and participation of various elements of society, ranging from culture, artists, local governments, and the West Kalimantan Malay community in general.

Awareness of the importance of maintaining and developing the traditional theater mendu is a milestone for the lives of these arts. Concrete steps are very much needed considering the fate of the traditional theater, its breath is already in the throat. The suspended animation situation is quite alarming.

\section{METHOD}

This research is a qualitative research with descriptive method[13][14][15]. Data collection techniques carried out by studying the text, namely literature study[16][17][18]. To complete the data, interviews and observations were made in the field. Interviews were conducted with Ilham Setia (32 years) director and actor of theMendu Pontianak art gallery, also to Syamsie Jar'i (64 years) director and scriptwriter (synopsis) Tirai Budayaart gallery Sungai Duri 1 of Mempawah Regency. The study was carried out by classifying the parts that were the object of research in this study. The steps of data collection are done through repeated reading on primary sources which are the object of research. Then record the parts and classify them. The classification is intended to separate the parts that are included as data to be analyzed, making it easier for researchers to relate it to the problems and objectives in this study. Data sources in this study are books, journals, writings, and documents. The data is in the form of text which shows comprehensive information about the existence of mendu in West Kalimantan

\section{RESULT AND DISCUSSION}

Regional culture is an integral part of national culture. The Malays in West Kalimantan have a distinctive culture in the form of folk art, namely the traditional theater of mendu. In 2014 the mendu traditional theater was designated as an intangible cultural heritage shared by West Kalimantan Province and Riau Islands by the Ministry of Education and Culture of the Republic of Indonesia. This must receive a positive appreciation as an effort by the central government to maintain and preserve the local culture which is essentially a national cultural treasure.

Malay art is an expression of the culture of the Malay people. It contains the Malay value system, which is used as a guide in culture. Malay art is an integral part of traditional institutions. Malay art in order to fill the era that is passed must be experiencing continuity and accompanied by changes. Malay art also experienced changes in accordance with the time he lived.Likewise, the traditional theater of mendu West Kalimantan has experienced ups and downs since its appearance. Mendu was very popular and became the belle of the community, especially in Mempawah, Pontianak and Sambas districts, during the royal period. However, after the entry of Japan and the period after independence, mendu suffered a setback. It was only at around the 80 's the mendu rose again and flourished in the community, among others thanks to the gait of the maestro mendu namely Sataruddin Ramli (1948 - 2015). Until now mendu experienced a state of 'apparent death'. 
Mendu, who was once popular in the past, is now very alarming. Indeed, the performing arts of the mendu are still staged at times, but their active supporters are diminishing. Fading or extinction of various forms of performance art is really alarming. Because, performance art is not merely function as entertainment as assumed by some people. Performing arts, as a social fact, are often 'the lives of the people who own them'. With that understanding, the fading or extinction of performing arts means the fading or extinction of the community of the owner[19].Malay art contributes various values to the development of culture nationally and transnationally, especially among the Malay family countries. Malay cultural arts also have a strategic role in the context of development at the regional scale (provincial, district, subdistrict and rural), as well as within the national and Malay world spheres. In making Malay art work in development, a variety of cultural strategies would be needed. Among these is that Malays must be able to read the signs of the times.

Technological advances should be able to support the development of a traditional art, not on the contrary kill tradition and culture in society. The roots of Malay performing arts culture are cultures inherited before outside influences and continue to be transformed when external influences come. The roots of this performing arts culture are part of strengthening Malay identity. Culturally, the Malay community has always responded and adopted the influence of outside art as part of world culture in general. This acculturation occurs in all forms and contents of culture. Pratt said these points of cultural intersection are tense areas where "disparate cultures meet, clash, and grapple with each other[20].However, this problem is not a problem in cultural acculturation in Indonesia in general, because the culture of the archipelago is very open to any culture on this earth[21].

The bad impact of globalization is not the only factor causing the decline of regional art, there are still many other factors that are also the main cause of the decline of the triumph of folk art. The following will explain some of the factors causing the decline in traditional theater mendu, among others, as follows.

\section{a. The rapid flow of globalization}

It is undeniable that Malay art, especially traditional theater, mendu has begun to be eroded by the times and globalization. But during the past three decades globalization reflects economic interdependence and cultural heterogeneity in many parts of the world resulting in not just the shifts of economic power, but also blurred national identity[22]. This assumption is reinforced by the suspicion of the influence of westernization. As westernization in various forms is still influential in the present context of globalization, much contemporary knowledge is highly manipulated by the West as a result of hundreds of years of colonization[23].

\section{b. Lack of role of local government.}

The role of the regional government is also highly expected to be able to preserve this art, for example in the form of guidance and financial assistance to the Mendu theater group that still exists. For example the Tirai Budaya art gallery in Sungai Duri 1 village Sungai Kunyit District Mempawah Regency. The art gallery, which was established in 2015, claimed not to get maximum attention from the local government of Mempawah district. It's just that they claimed to have been invited 5 times by the Regional Government of Mempawah Regency, for example in the anniversary of Mempawah, Mempawah Ekso, robo-robo cultural events and the Youth Pledge. A similar sentiment was expressed by Ilham Setia, the Mendu West Kalimantan Art gallery also received no serious attention from the Pontianak City Government or West Kalimantan Province. 
The role of policy makers in this case the central and regional governments are also very necessary. As is known, local wisdom is understood as local cultural treasures that are owned by residents in each region, known, valued, and discovered through various formats, namely oral, written, and action/behavior. Only unfortunately,Indonesia as a multi-ethnic and multicultural country has a lot of wealth that is often forgotten by policy makers[24].

The role of the local government can be implemented not only in the form of financial assistance, many things can be done such as policies on preservation of regional arts, coaching in the form of training, organizing folk theater festivals, integrated into the local content curriculum in schools, inviting groups to appear in the event national holidays, and other efforts deemed necessary as a form of preservation and development of the traditional theater of mendu.

\section{c. Lack of artist creativity.}

Artists' creativity is crucial in favoring a mendu performance. Starting from the neat stage, good lighting, adequate costumes, attractive overall appearance, to the storyline that is not monotonous and seem boring. Based on observations on the field in the performance of the Kerajaan Langkadura Tirai Budaya art gallery on August 19, 2019 at the Sungai Duri 1 soccer field, the enthusiasm of the community was very high to watch mendu. No less than 400 to 500 people thronged the field around the scum. Only unfortunately, this number only lasted up to half the show (about 1 hour), one by one the audience left the location of the show. Until the performance was finished, no more than 50 people were still at home watching.

\section{d. Mendu artists do not get a salary.}

Mendu artists do not get an honor either during training or staging. Only occasionally if they are invited by certain parties, and even then must be shared equally among all players so that the wages they get are also relatively small. they play voluntarily without expecting anything in return or reward because on average they are called to develop the soul of art and on the basis of awareness to preserve their native culture. This seems to be one of the factors that determines art gallery that can last a long time. Lots of art gallery cannot develop due to financial problems. The players are not given awards in the form of adequate rewards. It merely obtains inner satisfaction after the performance has been successfully performed. While on the other hand the actors need a living expense that is not small, even though their jobs are average as farmers, fishermen and unskilled laborers. If they work to get results and if they do not work (for example because they are preparing to perform) there is certainly no income. They should have obtained material benefits (wages) because the contributions they make are also very time-consuming and tiring. The problem that arises then is who will pay for their sweat? Is the art gallery a shelter (which also does not have adequate finance), or the local government (which also does not prepare a special fund for coaching)? What is clear, this problem becomes urgent for the sustainability of an art gallery.

\section{e. Lack of support from Malay customary council, Malay Kingdom and Culture.}

The Malay Cultural Customary Council, the Malay kingdom and cultural figures in West Kalimantan should be able to provide support and be the main facilitator in the efforts to preserve the ambassador. Many traditional events are held, but unfortunately rarely even ever performed traditional mendu theater.

\section{f. Lack of community support}


After the Reformasi, the public dwindles for various reasons, one of which was the decline of traditional arts in general in facing the onslaught of new kinds of globalized popular culture [25]. Mendu has been regarded as an outdated and impractical entertainment medium. This traditional theater is considered monotonous and does not provide satisfaction for the world of entertainment [26].

Nowadays, however, wayang, as well as other traditional theatres, faces the problem of extinction. Wayang theatres are often thought of as identical to performance arts for the old generation, entertainments for the aged, obsolete performances which are performed at unattractive places, boring stories; all these make wayang theatres unpopular and disliked by young generation. Whereas actually within wayang stories there contain some values of local wisdom which can be developed as one aspect of nation and character building[10].

\section{g. Mendu is not integrated in the local content curriculum both in schools and universities in West Kalimantan.}

One of the most effective means of electrifying mendu is to incorporate local content curricula in both schools and tertiary institutions. For example, in the Indonesian Language Education study program, and Regional Literature study program, it can be inserted mendu material or even mendu staging.

\section{CONCLUSION}

Who is the owner of mendu? The answer is the people of West Kalimantan as a whole, both the government, customary stakeholders, cultural figures, artists, and even the supporting communities. Mendu is the cultural heritage of West Kalimantan. Efforts to preserve traditional arts are certainly intended so that cultural heritage is not extinct. Therefore, regional arts need to be fostered, maintained, and preserved given their role in supporting national culture. Cultural preservation in general can be defined as any behavior or action aimed at maintaining the condition and existence of a legacy of past generations through an inventory, documentation and revitalization process.

The factors that are causing the decline in the traditional theater of Mendu must certainly find a solution in order to answer all existing problems. All parties must sit together, embracing each other for the realization of the cultural treasures that are the pride of the people of West Kalimantan.

\section{REFERENCES}

[1] P. A. \& T. Kusniarti., "Character and Local Wisdom-Based Instructional Model of Bahasa Indonesia in Vocational High Schools," J. Educ. Pract., vol. 8, no. 5, pp. $23-$ 29, 2007.

[2] Ismawati, "Sejarah Kesenian Ludruk Karya Budaya Mojokerto Tahun 1969-2009," AVATARA, e-Journal Pendidik. Sejarah., vol. 5, no. 3, pp. 1027-1041, 2017.

[3] I. Meliono., "Understanding the Nusantara Thought and Local Wisdom as an Aspect of the Indonesian Education.," TAWARIKH Int. J. Hist. Stud., vol. 2, no. 2, pp. 221234, 2011.

[4] M.P. Wangi, "Analisis Dramaturgi Banyolan Kartolo Episode Setoran di JTV Surabaya," Capture., vol. 3, no. 2, pp. 53-73, 2012.

[5] G. Wirawan., "Sejarah Mendu Kalimantan Barat.," in Proceeding Seminar Nasional Bahasa dan Sastra: Mengukuhkan Fungsi Bahasa dan Sastra untuk Memperkuat Jati Diri Bangsa, 2018, pp. 329-338. 
[6] Jefrizal, "Relevansi Kehidupan Sehari-hari dengan Seni Pertunjukan Tradisional.," J. Ilmu Budaya, vol. 14, no. 1, pp. 11-21, 2017.

[7] R. Taylor, "Turning up the Volume: A Study of the Wan Smolbag Theatre Company," 3L J. Lang. Teaching, Linguist. Lit., vol. 13, pp. 9-29, 2007.

[8] A. Badrun, Patu Mbojo. Mataram: Penerbit Langge, 2014.

[9] J. Vansina, Tradisi Lisan Sebagai Sejarah. Yogyakarta: Ombak, 2014.

[10] N.E. Wardani \& E. Widiyastuti, "Mapping Wayang Traditional Theatre as a Form of Local Wisdom of Surakarta Indonesia," Asian J. Soc. Sci. Humanit., vol. 2, no. 2, pp. 314-321, 2013.

[11] \& R. D.D. Paluseri, L.M. Syahdenal, Warisan Budaya Takbenda Indonesia Penetapan Tahun 2014. Jakarta: Direktorat Internalisasi Nilai dan Diplomasi Budaya, Direktorat Jenderal Kebudayaan, Kementerian Pendidikan dan Kebudayaan Republik Indonesia, 2014.

[12] L.Y. Fang, Sejarah Kesusastraan Melayu Klasik. Jakarta: Yayasan Pustaka Obor Indonesia, 2011.

[13] J.W. Creswell, Research Design: Qualitative, Quantitative, and Mixed Method Approaches. New Delhi: SAGE Publications, 2014.

[14] R.K. Yin, Qualitative Research: form Start to Finish. New York: The Guildford Press, 2011.

[15] P. Leavy., Qualitative, Quantitative, Mixed Method, Art-Besed, and Community Besed, Participatory Reasearch Approaches. New York: The Guilford Press, 2017.

[16] M. Nazir, Metode Penelitian. Jakarta: Ghalia Indonesia, 2003.

[17] J.U. Muliawan, Metode Penelitian Pendidikan dengan Studi Kasus. Yogyakarta: Penerbit Gava Media, 2014.

[18] M. Zed, Metode Penelitian Kepustakaan. Jakarta: Yayasan Obor Indonesia, 2008.

[19] C. Effendy, Becerite dan Bedande: Tradisi Kesastraan Melayu Sambas. Pontianak: STAIN Press, 2006.

[20] S. Milz., "Comparative Cultural Studies and Ethnic Minority Writing Today: The Hybridities of Marlene Nourbese Philip and Emine Sevgi Özdamar," CLCWeb Comp. Lit. Cult., vol. 2, no. 2, pp. 1-15, 2000.

[21] S. San, Semiotika Teater Bangsawan. Yogyakarta: Penerbit Ombak, 2018.

[22] I-C. Wang, "Globalization and Theater Spectacles in Asia," CLCWeb Comp. Lit. Cult., vol. 15, no. 2, pp. 1-9, 2013.

[23] M.R.W. Ahmad, "Finding God In Dinsman's It Is Not A Suicide: An Islamic Metaphysical Approach," GEMA Online J. Lang. Stud., vol. 13, no. 3, pp. 223-235, 2013.

[24] J.Huba, Analisis SWOT Kearifan Lokal dalam Resolusi Konflik. Jakarta: International Center for Islam and Pluralism (ICIP), 2007.

[25] M. Budianta, "Culture, power, and identity: the Case of Ang Hien Hoo," Wacana, vol. 18, no. 2, pp. 485-513, 2017.

[26] B.W. Setyawan and K. Saddhono, "Eret traditional ceremony as representation of spirit of mutual cooperation among coastal communities". Adv. Sci. Let. vol. 23 no.10, pp 9991-9992, 2017 